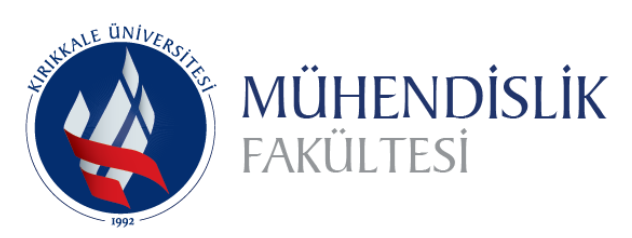
Uluslararası Mühendislik
Araştırma ve Geliştirme Dergisi UMAGD, (2020) 12(2), 631-637.
International Journal of
Engineering Research and
Development

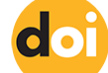
10.29137/umagd.705861

Cilt/Volume:12 Sayı/Issue:2 Haziran/June 2020

Araştırma Makalesi / Research Article

\title{
Major Ion Composition of Dry Deposition in Kirklareli, Turkey
}

\author{
İlker Oruç ${ }^{1}$ iD
}

Vocational College of Technical Sciences, Kirklareli University, Kirklareli, TURKEY

Başvuru/Received: 19/03/2020

Kabul / Accepted: 29/03/2020

Çevrimiçi Basım / Published Online: 30/06/2020

Son Versiyon/Final Version: 30/06/2020

\begin{abstract}
The chemical composition of dry deposition in Kirklareli (Turkey) is presented in this study. During the sampling period, in a total of 28 dry deposition samples which were collected in two stations which are Central District and Kaynarca Town, the concentrations of major cations $\left(\mathrm{Na}^{+}, \mathrm{Mg}^{2+}, \mathrm{Ca}^{2+}, \mathrm{K}^{+}, \mathrm{NH}_{4}^{+}\right)$and major anions $\left(\mathrm{Cl}^{-}, \mathrm{NO}_{3}{ }^{-}, \mathrm{SO}_{4}{ }^{2-}\right)$ were determined and $\mathrm{pH}$ values were also measured. In both sampling stations, arithmetic mean concentration values of major cations are $\mathrm{Ca}^{2+}>\mathrm{NH}_{4}{ }^{+}>\mathrm{K}^{+}>\mathrm{Na}^{+}>\mathrm{Mg}^{2+}$ and those of major anions are $\mathrm{SO}_{4}{ }^{2-}>\mathrm{Cl}^{-}>\mathrm{NO}_{3}{ }^{-}$in dry deposition samples. By calculating the enrichment factors (EF) of the chemical components and non-sea salt (NSS) concentration values, it has been aimed to determine the ion sources in the dry deposition. Nonsea salt fraction (NSSF) values of $\mathrm{Ca}^{2+}$ and $\mathrm{K}^{+}$ions are $99 \%$ and $96 \%$, respectively, in both sampling stations. Fluxes of dry deposition of ions were calculated. In both stations, among all ions, sulphate ion is the one which has the highest mean dry deposition flux value.
\end{abstract}

Key Words

"Dry deposition, ion concentration, enrichment factor" 


\section{Introduction}

Dry deposition includes the collection of atmospheric species directly on the surfaces without precipitation; also, it is a continuous and a slower process compared to wet deposition (Wallace and Hobbs, 2006). The level of atmospheric turbulance, chemical features of depositing species and the own nature of the surface are the factors that affect dry deposition of a particle or gaseous species. Particularly in the layer nearest to the surface, the level of turbulance in the atmosphere affects the speed of gaseous species to reach the ground (Seinfeld and Pandis, 2006). So as to relate dry deposition processes to various control factors, it is necessary to simultaneously measure the meteorological conditions and surface traits (Gong and Barrie, 2009). Generally, dry deposition can more effectively remove small particles close to the ground compared to sedimentation. The reason why dry deposition is more effective in particles than in gases is the fact that particles are heavier than gases (Jacobson, 2002). Coarse mode of aerosols and large particles which contain calcium and magnesium can perform dry deposition more effectively compared to fine particles (Akkoyun lu and Tayanç, 2003).

There are many studies related to the dry deposition analysis in the literature. Some results of such researches are given below. AlMomani et al. (1995), has showed that relatively greater dimensions of sea salt particles caused, on the mass of dry deposition, the high contribution of $\mathrm{Na}^{+}$and $\mathrm{Cl}^{-}$, sedimenting out in the adjacent coastline area where the station is situated. In dry deposition, ions contributed to total ion mass by $\mathrm{Na}^{+}(25.4 \%), \mathrm{Ca}^{2+}(7.4 \%), \mathrm{Mg}^{2+}(4.8 \%), \mathrm{K}^{+}(1.8 \%), \mathrm{NH}_{4}^{+}(0.5 \%), \mathrm{Cl}^{-}(40 \%), \mathrm{SO}_{4}{ }^{2-}(15.3 \%)$, and $\mathrm{NO}_{3}^{-}(4.9 \%)$. Another study by Ferm and Hultberg (1999), has demonstrated a large fraction of total atmospheric input for base cations which are $\mathrm{Na}^{+}(66 \%), \mathrm{Mg}^{2+}(67 \%), \mathrm{Ca}^{2+}(53 \%)$, and $\mathrm{K}^{+}(42 \%)$ within the dry deposition. According to the study of Rao et al. (1992), deposition rates varied in three different seasons. The maximum deposition rates were recorded during the winter season and these rates dropped to minimum in the monsoon season. The deposition rates were intermediate in the summer season. The annual average values of deposition fluxes of $\mathrm{Cl}^{-}, \mathrm{SO}_{4}{ }^{2-}, \mathrm{NO}_{3}{ }^{-}, \mathrm{NH}_{4}{ }^{+}, \mathrm{Na}^{+}, \mathrm{K}^{+}, \mathrm{Ca}^{2+}$, and $\mathrm{Mg}^{2+}$ were determined as $0.43,0.20,0.57,0.03$, $0.21,0.10,0.80$, and $0.12 \mathrm{~g} \mathrm{~m}^{-2} \mathrm{y}^{-1}$, respectively. The total deposition for $\mathrm{K}^{+}, \mathrm{Ca}^{2+}, \mathrm{Mg}^{2+}$, and $\mathrm{NO}_{3}^{-}$were higher than those for $\mathrm{Na}^{+}$, $\mathrm{Cl}^{-}, \mathrm{SO}_{4}{ }^{2-}$, and $\mathrm{NH}_{4}{ }^{+}$in terms of percentage contributions of dry deposition. The $26 \%$ of the total dry deposition was $\mathrm{SO}_{4}{ }^{2-}$ and $38 \%$ was $\mathrm{NO}_{3}{ }^{-}$. Furthermore, percentage of $\mathrm{Na}^{+}$was $24, \mathrm{~K}^{+}$was $40, \mathrm{Ca}^{2+}$ was 37 , and $\mathrm{Mg}^{2+}$ was 34 within the total dry deposition. Based on study of Akkoyunlu and Tayanç (2003), enrichment factors for wet and bulk deposition were generally observed much lower than the enrichment factors for dry deposition. As expected, this shows terrestrial sources are effective on the dry deposition as main sources. Enrichment factors of $\mathrm{Cl}^{-}$and $\mathrm{Mg}^{2+}$ were lower than those of $\mathrm{Ca}^{2+}, \mathrm{SO}_{4}{ }^{2-}$, and $\mathrm{K}^{+}$. $\mathrm{Cl}^{-}$and $\mathrm{Mg}^{2+}$ were less important on dry deposition because they mainly originate from sea. Inomata et al. (2009), have mentioned that the dry deposition flux of dust under circumstances of strong wind was dominated by local dust around the observation site. Dry deposition of chemical species which is water-soluble depicts the variation in the water vapor mixing ratio. Also, Inomata et al. (2009) and Budhavant et al. (2012) have determined that during the long-range transport, there was a connection between the dry deposition fluxes of water-soluble species and the emission and modification of dust.

In this work, dry deposition sampling was performed at two stations in Kirklareli. In samples of dry deposition; concentrations of major ions were measured, their sources were aimed to be determined and dry deposition fluxes were calculated.

\section{Materials and Methods}

Kirklareli is a border province located in the northwest part of the Turkey. Two sampling stations were selected in Kirklareli for dry deposition sampling. The sampling stations in Kirklareli are the Central District and Kaynarca Town of Pinarhisar District (Figure 1). Dry deposition samples were collected simultaneously from January $1^{\text {st }}$, 2015 to the end of July 2015 at the two stations. During this period, a total of 28 dry deposition samples, 14 of which were from Central District and the other 14 from Kaynarca Town, were collected. During the sampling period, in samples of dry deposition type; the concentrations of major cations $\left(\mathrm{Na}^{+}, \mathrm{Mg}^{2+}, \mathrm{Ca}^{2+}, \mathrm{K}^{+}\right.$, $\left.\mathrm{NH}_{4}{ }^{+}\right)$and major anions $\left(\mathrm{Cl}^{-}, \mathrm{NO}_{3}{ }^{-}, \mathrm{SO}_{4}{ }^{2-}\right)$ were found and $\mathrm{pH}$ values were also measured.

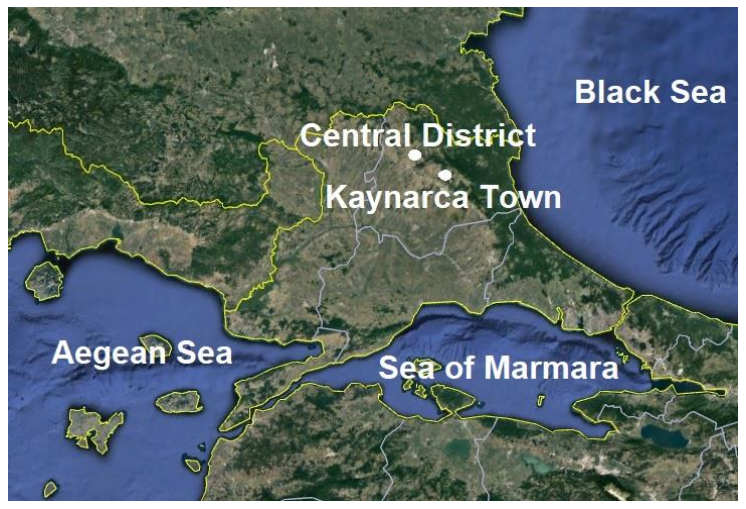

Figure 1. Sampling stations in Kirklareli. 
In dry deposition sampling, the sampling containers and funnels were rinsed with deionized water before the sampling, soaked with $5 \%$ nitric acid, rinsed again with deionized water and dried, then made ready for sampling. $60 \mathrm{~cm}$ diameter funnels were used in the sampling. Funnels were mounted at a height of $150 \mathrm{~cm}$ from the ground. This height is necessary to avoid mixing the ground dusts with the sampling funnels. Dry deposition sampling was carried out for 15 day periods in a high-ceiled area which is open to the atmosphere on the other sides, so as to block wet deposition, but not to affect dry deposition. Sampling funnels were rinsed with 1 liter of deionized water during dry deposition sampling. The rinsing water was transferred to polyethylene containers for analysis. The $\mathrm{pH}$ values of the samples transferred in polyethylene containers were measured immediately. The samples were stored in lightproof funnels before the chemical analysis, in pre-cleaned polyethylene containers at $4{ }^{\circ} \mathrm{C}$ in a refrigerator. Then, the samples were taken to the laboratory for analysis.

Hanna HI 9811-5 Portable $\mathrm{pH} / \mathrm{EC} / \mathrm{TDS} /{ }^{\circ} \mathrm{C}$ Meters device was used for $\mathrm{pH}$ measurement. While Ion Chromatography device was used for $\mathrm{Cl}^{-}, \mathrm{SO}_{4}{ }^{2-}, \mathrm{NO}_{3}{ }^{-}$, and $\mathrm{NH}_{4}{ }^{+}$analysis, ICP/OES (SPECTRO ARCOS) device was engaged for $\mathrm{Ca}^{2+}, \mathrm{Mg}^{2+}, \mathrm{K}^{+}$, and $\mathrm{Na}^{+}$ analysis.

The enrichment factors (EF) for seawater is defined as (Okay et al., 2002; Akkoyunlu and Tayanç, 2003);

$$
\mathrm{EF}=\frac{(\mathrm{X} / \mathrm{C})_{\text {precipitation }}}{(\mathrm{X} / \mathrm{C})_{\text {reference material }}}
$$

The non-sea salt (NSS) concentration of ions is determined with the equation below (Okay et al., 2002; Akkoyunlu and Tayanç, 2003).

$$
\text { NSS }=\text { Total }_{\mathrm{p}}-\mathrm{C}_{\mathrm{p}}\left(\mathrm{X}_{\mathrm{r}} / \mathrm{C}_{\mathrm{r}}\right)
$$

In the equations; $\mathrm{X}$ shows the corresponding ion concentration and $\mathrm{C}$ represents the reference ion concentration. The subscript of $\mathrm{p}$ gives the ions in the precipitation, while $\mathrm{r}$ subscript represents the ions in the reference material. NSSF is presented as the ratio of non-sea salt concentration to total concentration (Akkoyunlu and Tayanç, 2003).

In this study, the concentration values of ions in sea surface water were used (Brewer, 1975) and by taking sodium as the reference element, the enrichment factors of ions in dry deposition type were calculated.

Dry deposition flux is acquired by using the equation below (Zobrist et al., 1993).

$$
\mathrm{F}=\frac{\mathrm{C} \Delta \mathrm{V}}{\mathrm{A} \Delta \mathrm{t}}
$$

In the equation, $\mathrm{F}$ is dry deposition flux $\left(\mathrm{mg} \mathrm{m}^{-2} \mathrm{~d}^{-1}\right), \mathrm{C}$ is concentration (rinsing water included) $\left(\mathrm{mg} \mathrm{L}^{-1}\right), \Delta \mathrm{V}$ is volume (rinsing water included) (L), $A$ is the area of the surface where dry deposition takes place $\left(\mathrm{m}^{2}\right)$ and $\Delta \mathrm{t}$ is the period of dry deposition (d).

\section{Results and Discussion}

The $\mathrm{pH}$ values of dry deposition samples are between 6.55 to 7.71 in the Central District and 6.52 to 7.75 in the Kaynarca Town. The mean $\mathrm{pH}$ values of dry deposition samples in the Central District and Kaynarca Town are 7.00 and 7.07, respectively. The samples with the highest frequency values in the Central District (64.29\%) had a pH values of 6.5-7.0, while the highest frequency values in the Kaynarca Town (50.00\%) was between 7.0-7.5 (Figure 2). All of the dry deposition type samples are alkaline in two stations at Kirklareli.

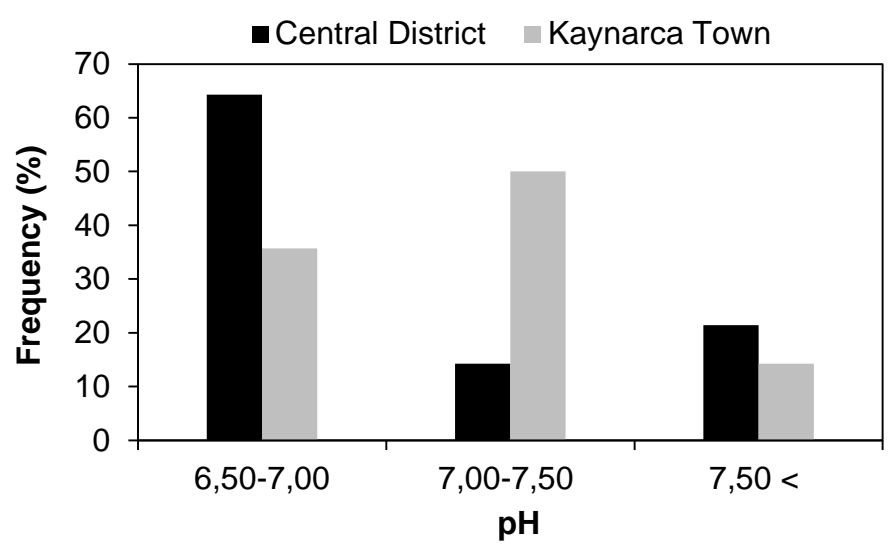

Figure 2. Frequency distribution of $\mathrm{pH}$ values in dry deposition samples. 
The average concentrations of major ions in dry deposition in Kirklareli are shown in Figure 3. The average concentration values of all ions except the $\mathrm{SO}_{4}{ }^{2-}$ ion in Kaynarca Town was found to be higher than the average concentration values of all ions in Central District (2-30\%). The arithmetic mean concentrations of major ions for the dry deposition in the two sampling stations tend to show a similar trend: $\mathrm{SO}_{4}{ }^{2-}>\mathrm{Ca}^{2+}>\mathrm{Cl}^{-}>\mathrm{NH}_{4}{ }^{+}>\mathrm{NO}_{3}{ }^{-}>\mathrm{K}^{+}>\mathrm{Na}^{+}>\mathrm{Mg}^{2+}$. In Central District, mean concentration values of these ions, respectively, are $6.33,4.37,3.15,1.54,0.90,0.59,0.52,0.32 \mathrm{mg} \mathrm{L}^{-1}$ and in Kaynarca Town 6.12, 4.81, 4.46, 1.59, 0.92, 0.78, 0.58, $0.37 \mathrm{mg} \mathrm{L}^{-1}$ respectively. The dominant cation is $\mathrm{Ca}^{2+}$, and the dominant anion is $\mathrm{SO}_{4}{ }^{2-}$ in both sampling stations. In the study performed in Kirklareli city (Turkey), it has been stated that the dominant cation was found to be $\mathrm{Ca}^{2+}$ and dominant anion to be $\mathrm{SO}_{4}{ }^{2-}$ in dry deposition in both urban and rural areas (Oruc et al., 2012).

Many stone-soil industrial plants are located near sampling areas. Calcium, which is in urban and rural sediments, building materials and soil, mixes into the troposphere as a result of wind erosion. Despite the high concentration of $\mathrm{SO}_{4}{ }^{2-}$, the high $\mathrm{Ca}^{2+}$ concentration may be presented as the main reason for the fact that dry deposition samples are alkaline in sampling areas. Besides, apart from stone-soil plants, other various industrial plants are situated near the sampling areas. $\mathrm{SO}_{2}$ emission caused by fossil fuels used for heating and industrial activities can be shown as the basic reason for high concentration of $\mathrm{SO}_{4}^{2-}$ in dry deposition samples. Neutralization factors showed that calcium has a vital part in the process of neutralization, which probably indicates the presence of $\mathrm{Ca}\left(\mathrm{NO}_{3}\right)_{2}$ and $\mathrm{CaSO}_{4}$ in the atmosphere, which takes its origin from alkaline particles which emerge from the Earth's crust and the cement plants, and from $\mathrm{SO}_{2}$ and $\mathrm{NO}_{\mathrm{x}}$ which are given out in burning processes in power plants (Cerón et al., 2012).

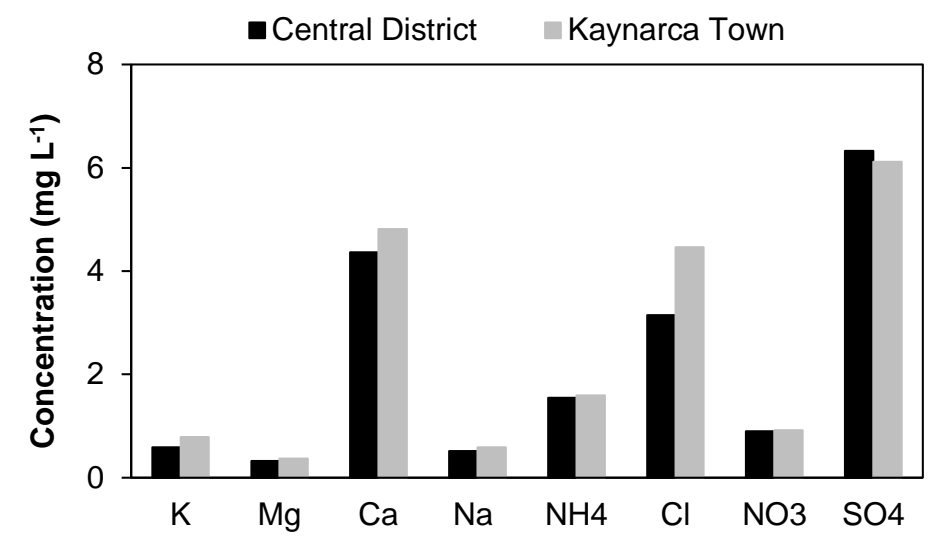

Figure 3. Arithmetic mean concentrations of major ions in dry deposition.

The flux allows calculating the amount of particles settled per unit time to per unit area. In Kaynarca Town, except the $\mathrm{SO}_{4}{ }^{2-}$ ion, the mean dry deposition flux values of all the ions have been determined to be higher than the average dry deposition flux values of ions in the Central District. The $\mathrm{SO}_{4}{ }^{2-}$ ion has the highest average flux value in both stations. The average dry deposition flux of this ion is $1.49 \mathrm{mg} \mathrm{m}^{-2} \mathrm{~d}^{-1}$ in the Central District and $1.44 \mathrm{mg} \mathrm{m}^{-2} \mathrm{~d}^{-1}$ in Kaynarca Town. Except the $\mathrm{SO}_{4}{ }^{2-}$ ion, the average dry deposition fluxes of ions were determined as $\mathrm{Ca}^{2+}>\mathrm{Cl}^{-}>\mathrm{NH}_{4}{ }^{+}>\mathrm{NO}_{3}{ }^{-}>\mathrm{K}^{+}>\mathrm{Na}^{+}>\mathrm{Mg}^{2+}$ in both stations (Figure 4). In Central District, mean dry deposition flux values of these ions are 1.03, 0.74, 0.36, 0.21, 0.14, 0.12, $0.08 \mathrm{mg} \mathrm{m}^{-2} \mathrm{~d}^{-1}$ respectively, and in Kaynarca Town 1.14 , $1.05,0.37,0.22,0.18,0.14,0.09 \mathrm{mg} \mathrm{m}^{-2} \mathrm{~d}^{-1}$ respectively.

It is observed that the dry deposition mechanism in the period of precipitation absence is more effective in Kaynarca Town than Central District. More dust-source particulate matter emissions took place in Kaynarca Town than the Central District. The large particle diameter of crustal aerosols also caused the greater rates of dry deposition of crustal ions. Apart from the particle sizes, comparably high dry deposition fluxes in regions, in which rain events are rare, are brought about by the unceasing nature of dry deposition processes (Al-Momani et al., 1995). Dry deposition of particles is dependent upon their dry-deposition velocities that are dependent upon sizes of particles. In general, large particles settle rapidly from the atmosphere and they have high dry-deposition velocities. Besides this effect of size, mainly dry-deposition mechanism removes the crustal particles from the atmosphere due to atmospheric loading of soil particles (Kaya and Tuncel, 1997). 


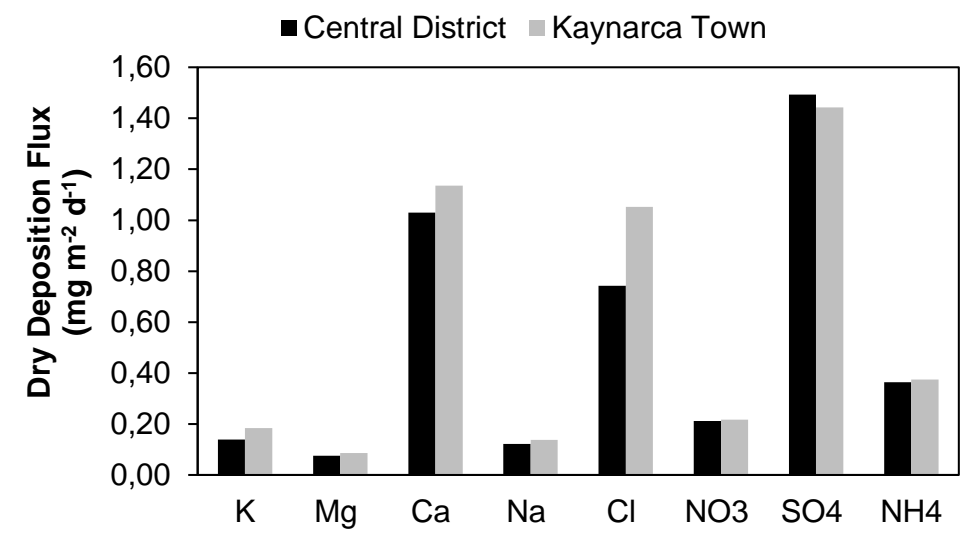

Figure 4. Arithmetic mean dry deposition fluxes in sampling stations.

The $\mathrm{Ca}^{2+}$ ion has the highest average EF values among all the ions in deposition samples, both in the Central District and in the Kaynarca Town (289.68 and 339.60, respectively) (Figure 5). The main source of $\mathrm{Ca}^{2+}$ ion is terrestrial by $99 \%$ in both sampling stations. The average EF value of the $\mathrm{SO}_{4}{ }^{2-}$ ion is 91.84 in the Central District, while 56.03 in the $\mathrm{Kaynarca}$ Town. The $\mathrm{SO}_{4}{ }^{2-}$ ion is anthropogenic-origin in Central District and Kaynarca Town with 98 percent and 97 percent, respectively. The average EF value of $\mathrm{K}^{+}$ion in Central District and Kaynarca Town are 51.68 and 42.55, respectively. In both sampling stations, the NSSF value of this ion is 96 percent and soil is the main source of this ion. Also in both sampling stations, among the ions, $\mathrm{Mg}^{2+}$ and $\mathrm{Cl}^{-}$ions have the lowest average EF values. The $\mathrm{Mg}^{2+}$ ion is non-marine origin in Central District and Kaynarca Town with 77 percent and 67 percent, respectively. The $\mathrm{Cl}^{-}$ion is marine origin in Central District and Kaynarca Town with 31 percent and 26 percent, respectively. EF values of $\mathrm{Ca}^{2+}, \mathrm{SO}_{4}{ }^{2-}$, and $\mathrm{K}^{+}$are higher compared to those of $\mathrm{Mg}^{2+}$ and $\mathrm{Cl}^{-}$. Similar results have been acquired in the study carried out by Akkoyunlu and Tayanç (2003), and those findings indicate that percentage of sea origin $\mathrm{Mg}^{2+}$ and $\mathrm{Cl}^{-}$is higher than that of $\mathrm{Ca}^{2+}, \mathrm{SO}_{4}{ }^{2-}$, and $\mathrm{K}^{+}$, and thus they show that in dry deposition $\mathrm{Mg}^{2+}$ and $\mathrm{Cl}^{-}$ions have less significance compared to $\mathrm{Ca}^{2+}$, $\mathrm{SO}_{4}{ }^{2-}$, and $\mathrm{K}^{+}$ions.
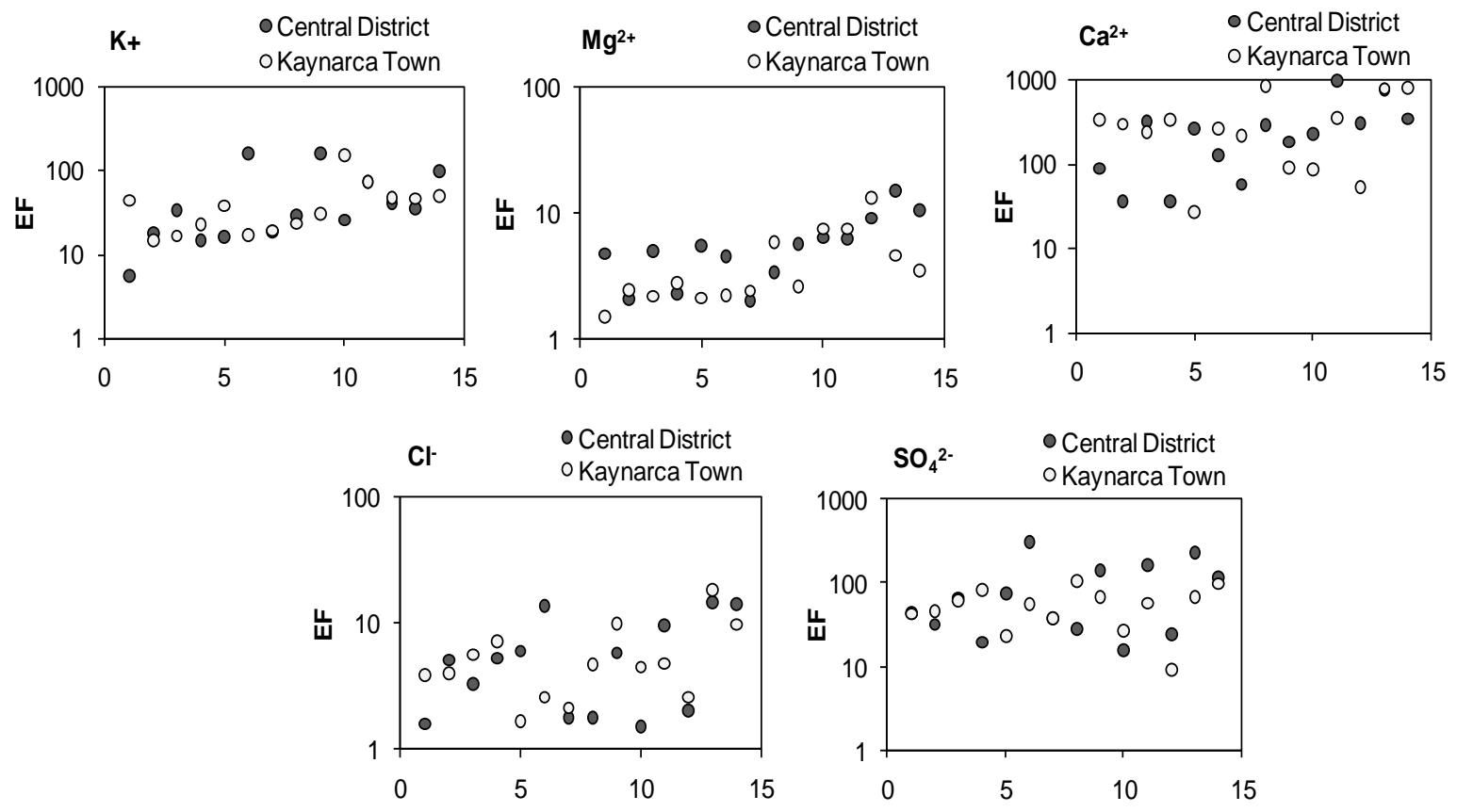

Figure 5. Enrichment factor values of the ions. 


\section{Conclusions}

In the dry deposition samplings simultaneously carried out in Central District and Kaynarca Town, the order of magnitude of arithmetic mean concentration values of major cations and major anions, respectively, is $\mathrm{Ca}^{2+}>\mathrm{NH}_{4}{ }^{+}>\mathrm{K}^{+}>\mathrm{Na}^{+}>\mathrm{Mg}^{2+}$ and $\mathrm{SO}_{4}{ }^{2-}>$ $\mathrm{Cl}^{-}>\mathrm{NO}_{3}{ }^{-}$. Minimum, maximum, mean $\mathrm{pH}$ values of dry deposition samples in Central District are, respectively, 6.55, 7.71, 7.00, and in Kaynarca Town 6.52, 7.75, 7.07. While samples in Central District, $\mathrm{pH}$ values of which vary between 6.5-7.0, have the highest frequency value (64.29\%), in Kaynarca Town samples whose $\mathrm{pH}$ values vary between 7.0-7.5 have the highest frequency value $(50.00 \%)$.

The main reason for the fact that all of the dry deposition samples collected in two sampling stations in Kirklareli are alkaline, is the high $\mathrm{Ca}^{2+}$ concentration which is in urban and rural sediments, building materials and soil, and thus mixes into the troposphere as a result of wind erosion. Within the sampling area, emissions stemming from heating and industrial activities can be shown as the primary reason for high $\mathrm{SO}_{4}{ }^{2-}$ concentration. Terrestrial origin $\mathrm{Ca}^{2+}$, which is the most effective ion upon alkalinity, and anthropogenic origin $\mathrm{SO}_{4}{ }^{2-}$ ions have the highest mean concentrations among the ions in both sampling stations. The dominant cation is $\mathrm{Ca}^{2+}$, and the dominant anion is $\mathrm{SO}_{4}{ }^{2-}$ in both sampling stations.

The magnitudes of dry deposition fluxes of the ions showed a similar trend both in Central Distrcit and Kaynarca Town; $\mathrm{SO}_{4}{ }^{2-}>\mathrm{Ca}^{2+}$ $>\mathrm{Cl}^{-}>\mathrm{NH}_{4}{ }^{+}>\mathrm{NO}_{3}{ }^{-}>\mathrm{K}^{+}>\mathrm{Na}^{+}>\mathrm{Mg}^{2+}$. Mean dry deposition fluxes of ions (except for $\mathrm{SO}_{4}{ }^{2-}$ ion), have higher values in Kaynarca Town compared to Central District. More dust source particulate matter emissions in Kaynarca Town than in the Central District, makes the dry deposition mechanism more effective than Central District in Kaynarca Town.

Both in Central District and Kaynarca Town, among ions, $\mathrm{Ca}^{2+}, \mathrm{SO}_{4}{ }^{2-}$, and $\mathrm{K}^{+}$ions respectively have the highest mean $\mathrm{EF}$ values. $\mathrm{EF}$ values of $\mathrm{Ca}^{2+}$ and $\mathrm{SO}_{4}^{2-}$ ions in Central District are, respectively, 289.68 and 91.84, and in Kaynarca Town 339.60 and 56.03 respectively. These ions have non-marine origin in Central District with the ratio of $99 \%$ and $98 \%$ respectively, and in Kaynarca Town $99 \%$ and $97 \%$ respectively. The main source of $\mathrm{K}^{+}$ion is soil by $96 \%$ in both Central District and Kaynarca Town. Percentages of non-marine origin $\mathrm{Ca}^{2+}, \mathrm{SO}_{4}^{2-}$, and $\mathrm{K}^{+}$are higher than those of $\mathrm{Mg}^{2+}$ and $\mathrm{Cl}^{-}$and thus $\mathrm{Ca}^{2+}, \mathrm{SO}_{4}^{2-}$, and $\mathrm{K}^{+}$ions are of a greater importance compared to $\mathrm{Mg}^{2+}$ and $\mathrm{Cl}^{-}$ions in dry deposition.

\section{References}

Akkoyunlu, B.O., \& Tayanç, M. (2003). Analyses of wet and bulk deposition in four different regions of Istanbul, Turkey. Atmospheric Environment, 37(25): 3571-3579. Doi.org/10.1016/S1352-2310(03)00349-2

Al-Momani, I.F., Tuncel, S., Eler, Ü., Örtel, E., Sirin, G., \& Tuncel, G. (1995). Major ion composition of wet and dry deposition in the eastern Mediterranean basin. The Science of the Total Environment, 164(1): 75-85. Doi.org/10.1016/0048-9697(95)04468-G

Brewer, P.G. (1975). Minor Elements in Seawater. In: Chemical Oceanography, Riley, J.P., Skirrow, G., (Eds.), Second Edition, Volume 1, Academic Press, London, UK, 415-496. ISBN: 0-12-588601-2

Budhavant, K.B., Rao, P.S.P., Safai, P.D., Gawhane, R.D., Raju, M.P., Mahajan, C.M., \& Satsangi, P.G. (2012). Atmospheric Wet and Dry Depositions of Ions over an Urban Location in South-West India. Aerosol and Air Quality Research, 12(4): 561-570. Doi: 10.4209/aaqr.2011.12.0233

Cerón, R.M., Cerón, J.G., Carballo, C.G., Aguilar, C., Montalvo, C., Vargas, C., Ortinez, J.A., Cárdenas, B., Córdova, A.V., \& Rodríguez, M.A. (2012). Chemical characterization of dry deposition of pollutants in one industrial site in Guanajuato, Mexico. International Journal of Energy and Environment. 6(5): 532-539.

Ferm, M., \& Hultberg, H. (1999). Dry deposition and internal circulation of nitrogen, sulphur and base cations to a coniferous forest. Atmospheric Environment, 33(27): 4421-4430. Doi.org/10.1016/S1352-2310(99)00211-3

Gong, S., \& Barrie, L.A. (2009). The Distribution of Atmospheric Aerosols: Transport, Transformation and Removal. In: Aerosol Pollution Impact on Precipitation, Levin, Z. \& Cotton, W.R., (Eds.), Springer, Dordrecht, 91-141. ISBN: 978-1-4020-8689-2

Inomata, Y., Igarashi, Y., Chiba, M., Shinoda, Y., \& Takahashi H. (2009). Dry and wet deposition of water-insoluble dust and watersoluble chemical species during spring 2007 in Tsukuba, Japan. Atmospheric Environment, 43(29): 4503-4512. Doi.org/10.1016/j.atmosenv.2009.06.048

Jacobson, M.Z. (2002). Atmospheric Pollution History, Science, and Regulation, First Edition, Cambridge University Press, Cambridge, UK, ISBN: 9780521010443

Kaya, G., \& Tuncel, G. (1997). Trace Element and Major Ion Composition of Wet and Dry Deposition in Ankara, Turkey. Atmospheric Environment, 31(23): 3985-3998. Doi.org/10.1016/S1352-2310(97)00221-5

Oruc, I., Akkoyunlu, B.O., \& Erdogan, I. (2012). Analysis of Wet, Bulk and Dry Deposition Chemistry in Kirklareli, Turkey. Unitech 12th International Scientific Conference, November 16-17, Gabrovo-Bulgaria, Volume II, 391-394. ISSN:1313-230X 
Okay, C., Akkoyunlu, B.O., \& Tayanç, M. (2002). Composition of Wet Deposition in Kaynarca, Turkey. Environmental Pollution, 118(3): 401-410. Doi.org/10.1016/S0269-7491(01)00292-5

Rao, P.S.P., Khemani, L.T., Momin, G.A., Safai, P.D., \& Pillai, A.G. (1992). Measurements of Wet and Dry Deposition at An Urban Location in India. Atmospheric Environment. Part B. Urban Atmosphere, 26(1): 73-78. Doi.org/10.1016/0957-1272(92)90038-T

Seinfeld, J.H., \& Pandis, S.N. (2006). Atmospheric Chemistry and Physics From Air Pollution to Climate Change. Second Edition, John Wiley\&Sons, Inc., Hoboken, NJ, USA, ISBN-13: 978-0-471-72018-8

Wallace, J.M., \& Hobbs, P.V. (2006). Atmospheric Science An Introductory Survey. Second Edition, Elsevier Inc., San Diego, CA, USA, ISBN 13: 978-0-12-732951-2

Zobrist, J., Wersin, P., Jaques, C., Sigg, L., \& Stumm, W. (1993). Dry deposition measurements using water as a receptor: A chemical approach. Water, Air, and Soil Pollution. 71: 111-130. Doi.org/10.1007/BF00475515 